\title{
Hydrogen peroxide is involved in hydrogen sulfide-induced lateral root formation in tomato seedlings
}

\author{
Yudong Mei ${ }^{1}$, Haotian Chen ${ }^{2}$, Wenbiao Shen ${ }^{1}$, Wei Shen ${ }^{2}$ and Liqin Huang ${ }^{2 *}$
}

\begin{abstract}
Background: Both hydrogen sulfide $\left(\mathrm{H}_{2} \mathrm{~S}\right)$ and hydrogen peroxide $\left(\mathrm{H}_{2} \mathrm{O}_{2}\right)$ are separately regarded as a highly reactive molecule involved in root morphogenesis. In this report, corresponding causal link governing lateral root formation was investigated.

Methods: By using pharmacological, anatomic, and molecular approaches, evidence presented here revealed the molecular mechanism underlying tomato lateral root development triggered by $\mathrm{H}_{2} \mathrm{~S}$.

Results: $\mathrm{A} \mathrm{H}_{2} \mathrm{~S}$ donor sodium hydrosulfide ( $\mathrm{NaHS}$ ) triggered the accumulation of $\mathrm{H}_{2} \mathrm{O}_{2}$, the up-regulation of $\mathrm{RBOH} 1$ transcript, and thereafter tomato lateral root formation. Above responses were sensitive to the $\mathrm{H}_{2} \mathrm{O}_{2}$ scavenger (dimethylthiourea; DMTU) and the inhibitor of NADPH oxidase (diphenylene idonium; DPI), showing that the accumulations of $\mathrm{H}_{2} \mathrm{O}_{2}$ and increased $\mathrm{RBOH} 1$ transcript were respectively prevented. Lateral root primordial and lateral root formation were also impaired. Further molecular evidence revealed that $\mathrm{H}_{2} \mathrm{~S}$-modulated gene expression of cell cycle regulatory genes, including up-regulation of SICYCA2;1, SICYCA3;1, and SICDKA1, and the down-regulation of SIKRP2, were prevented by the co-treatment with DMTU or DPI. Above mentioned inducing phenotypes were consistent with the changes of lateral root formation-related microRNA transcripts: up-regulation of miR390a and miR160, and with the opposite tendencies of their target genes (encoding auxin response factors). Contrasting tendencies were observed when DMTU or DPI was added together. The occurrence of $\mathrm{H}_{2} \mathrm{~S}$-mediated $\mathrm{S}$-sulfhydration during above responses was preliminarily discovered.
\end{abstract}

Conclusions: Overall, these results suggested an important role of $\mathrm{RBOH} 1$-mediated $\mathrm{H}_{2} \mathrm{O}_{2}$ in $\mathrm{H}_{2} \mathrm{~S}$-elicited tomato lateral root development, and corresponding $\mathrm{H}_{2} \mathrm{~S}$-target proteins regulated at transcriptional and post-translational levels.

Keywords: Hydrogen sulfide $\left(\mathrm{H}_{2} \mathrm{~S}\right)$, Hydrogen peroxide $\left(\mathrm{H}_{2} \mathrm{O}_{2}\right)$, Solanum lycopersicum, Lateral root formation, miRNA, S-sulfhydration

\section{Background}

Lateral root (LR) formation, which entirely originated from pericycle founder cells, is of critical importance for the plant root architecture [1]. Normally, LR formation depends on both genetic determinants and postembryonic developmental processes that are mainly under the influence of plant hormone (usually auxin) and environmental factors, including water and nutrient availability $[1,2]$. Genetic and molecular evidence revealed that

\footnotetext{
* Correspondence: lqhuangs@njau.edu.cn

${ }^{2}$ College of Sciences, Nanjing Agricultural University, Nanjing 210095, China Full list of author information is available at the end of the article
}

auxin regulates LR formation by modulating the transcripts of cell cycle regulatory genes, such as cyclins and Cyclin Dependent Kinases (CDK) in the pericycle cells [3-6]. Previous results showed that nitric oxide (NO) mediated the activation of auxin-dependent cell cycle regulatory genes encoding CYCA2;1, CYCA3;1, CDKA1, and the cell cycle inhibitor Kip-Related Protein KRP2 in tomato seedlings at the beginning of LR primordia formation [6]. On the other hand, auxin response factors (ARFs) appeared to play an essential role in auxinregulated gene expression during plant development, including LR formation, etc. [7-9]. A decade ago, a class 
of small, non-coding RNAs, called microRNAs (miRNAs), was identified to regulate gene expression $[10,11]$. Several miRNAs related to ARFs have been detected via computational approaches [12], such as miR390 targeting $A R F 2, A R F 3$ and ARF4 [13], while miR160 targeting ARF10, ARF16 and ARF17 [14].

After NO and carbon monoxide (CO) [15], hydrogen sulfide $\left(\mathrm{H}_{2} \mathrm{~S}\right)$ is proposed as the third gaseous messenger to be involved in guard cell signaling [16], root organogenesis [17], and the alleviation of seed germination inhibition caused by heavy metal exposure [18]. In mammalian cells, $\mathrm{H}_{2} \mathrm{~S}$ can be endogenously generated from four enzymes, such as cystathionine- $\gamma$-lyase (CSE), cystathionine- $\beta$-synthase (CBS), cysteine aminotransferase, and 3-mercaptopyruvate sulfurtransferase (3-MST) $[19,20]$. In plants, $\mathrm{H}_{2} \mathrm{~S}$ synthesis is partially catalyzed by ${ }_{\mathrm{L}}$-cysteine desulfhydrase (DES; homolog with CSE in animals) [21, 22]. Related experiments discovered that $\mathrm{H}_{2} \mathrm{~S}$ might be involved in auxin-induced LR formation in tomato seedlings [23]. Importantly, the discovered mechanism of physiological effects achieved by $\mathrm{H}_{2} \mathrm{~S}$ in animals and recently in plants is $S$-sulfhydration: a posttranslational modification of protein cysteine residues (persulfide R-SSH formation) [24-26]. Above modification manner is opposed to $S$ nitrosylation, another posttranslational modification of protein cysteine residues by $\mathrm{NO}$ with the formation of $S$-nitrosocysteine residues (R-SNO) [27]. However, whether protein $S$-sulfhydration was involved in $\mathrm{H}_{2} \mathrm{~S}$ mediated LR formation, is still unknown.

It was well-known that hydrogen peroxide $\left(\mathrm{H}_{2} \mathrm{O}_{2}\right)$ plays various vital roles in signal transduction beside its toxic effects. In fact, $\mathrm{H}_{2} \mathrm{O}_{2}$ is an important product of $\mathrm{NADPH}$ oxidase, polyamine oxidases (PAO), and diamine oxidases (DAO), etc. [28, 29]. Subsequent results showed that $\mathrm{H}_{2} \mathrm{O}_{2}$ mediates plant responses against adversity stresses and takes part in plant development processes, including stomatal closure [30], root gravitropism [31], and cell elongation [32]. Specially, $\mathrm{H}_{2} \mathrm{O}_{2}$ is also involved in auxin signaling [31,33,34], adventitious rooting [34, 35], and LR formation [36-39].

Although $\mathrm{H}_{2} \mathrm{~S}$ and $\mathrm{H}_{2} \mathrm{O}_{2}$ were respectively suggested to be required for root architecture [17, 32], the crosstalk between $\mathrm{H}_{2} \mathrm{~S}$ and $\mathrm{H}_{2} \mathrm{O}_{2}$ in tomato LR development, has not been fully elucidated. In this report, the analysis of $\mathrm{H}_{2} \mathrm{~S}$-regulated mechanisms leading to LR promotion is expanded. By using pharmacological, anatomic, and molecular approaches, evidence presented here supported the role of $R B O H 1$-mediated $\mathrm{H}_{2} \mathrm{O}_{2}$ in the regulation of tomato LR development achieved by $\mathrm{H}_{2} \mathrm{~S}$. Potential mechanisms, including LR-related ARFs gene expression via miRNAs, are preliminarily elucidated. Additionally, downstream signaling events modulated by $\mathrm{H}_{2} \mathrm{~S}$ might occur in both transcriptional and posttranslational levels (protein $S$-sulfhydration, etc.). Above results thus provide insights into $\mathrm{H}_{2} \mathrm{~S}$ signaling in plant development.

\section{Results}

Increases of endogenous $\mathrm{H}_{2} \mathrm{O}_{2}$ contents and LR formation elicited by NaHS

Compared with NaHS alone, the decreased $\mathrm{H}_{2} \mathrm{~S}$ production (determined by spectrophotography) and thereafter the impaired LR formation were previously observed when hypotaurine ( $\mathrm{HT} ;$ a $\mathrm{H}_{2} \mathrm{~S}$ scavenger) was added together with NaHS [23]. To further confirm whether above $\mathrm{NaHS}$ response was $\mathrm{H}_{2} \mathrm{~S}$-dependent, a commercial specific fluorescent probe AzMC for $\mathrm{H}_{2} \mathrm{~S}$ was applied. As expected, when together with $\mathrm{HT}$ or $\mathrm{DL}_{\text {-propargylgly- }}$ cine (PAG; a synthetic inhibitor of $\mathrm{H}_{2} \mathrm{~S}$ ), AzMC-related florescent density and LR formation achieved by NaHS were impaired as well (Fig. 1a-e). Above results clearly confirmed that the response of NaHS in the induction of LR formation was $\mathrm{H}_{2} \mathrm{~S}$-dependent.

Further, seedlings were loaded with reactive oxygen species (ROS)-specific fluorescent dye $\mathrm{H}_{2} \mathrm{DCF}-\mathrm{DA}$, and laser confocal scanning microscopy (LCSM) was used to investigate changes in ROS-induced fluorescence. Meanwhile, exogenously applied with $\mathrm{H}_{2} \mathrm{O}_{2}$ was regarded as a positive control. Figure $2 \mathrm{a}$ and $\mathrm{b}$ showed the images and quantified the fluorescence levels detected in $\mathrm{H}_{2} \mathrm{O}_{2}$ treated seedlings in the presence or absence of DMTU (a $\mathrm{H}_{2} \mathrm{O}_{2}$ scavenger) or DPI (an inhibitor of NADPH oxidase). Results revealed that both DMTU and DPI reduced, at least partially, the DCF-dependent fluorescence in the root tissues, consistent with the explanation that some, if not most, of the fluorescence was caused by endogenous $\mathrm{H}_{2} \mathrm{O}_{2}$. Thus, the fluorescence was used to report endogenous $\mathrm{H}_{2} \mathrm{O}_{2}$ levels throughout this study.

Subsequent results revealed that endogenous $\mathrm{H}_{2} \mathrm{O}_{2}$ production was induced as well when NaHS was applied, since the DCF-dependent fluorescence was increased by $56 \%$, compared to the control samples (Fig. 1b, d). By contrast, the addition of HT and PAG weaken above fluorescence induced by NaHS, suggesting that NaHSinduced $\mathrm{H}_{2} \mathrm{O}_{2}$ might be obviously blocked by the removal of $\mathrm{H}_{2} \mathrm{~S}$. Meanwhile, HT or PAG alone, not only decreased corresponding fluorescence, but also inhibited LR formation (Fig. 1e). Combined with the changes in LR density and its number, we thus speculated a potential interrelationship between endogenous $\mathrm{H}_{2} \mathrm{~S}$ and $\mathrm{H}_{2} \mathrm{O}_{2}$ during lateral root formation.

\section{$\mathrm{H}_{2} \mathrm{~S}$-induced tomato lateral rooting is sensitive to the removal of $\mathrm{H}_{2} \mathrm{O}_{2}$}

To investigate the contribution of $\mathrm{H}_{2} \mathrm{O}_{2}$ during $\mathrm{LR}$ formation triggered by $\mathrm{H}_{2} \mathrm{~S}$, DMTU and DPI were used together with $\mathrm{NaHS}$ and $\mathrm{H}_{2} \mathrm{O}_{2}$ to evaluate tomato $\mathrm{LR}$ 


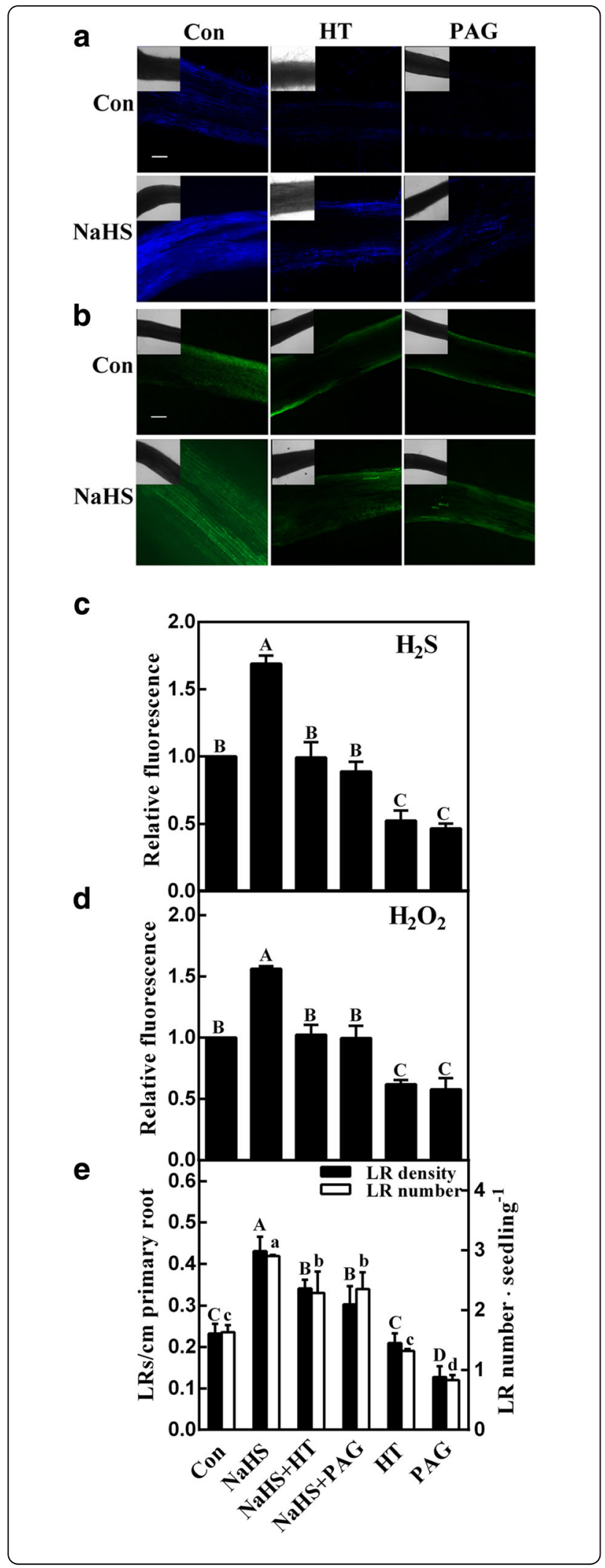

Fig. 1 Sodium hydrosulfide ( $\mathrm{NaHS}$; the $\mathrm{H}_{2} \mathrm{~S}$ donor) increases $\mathrm{H}_{2} \mathrm{O}_{2}$ accumulation and thereafter lateral root (LR) formation. Three-day-old tomato seedlings were treated with $\mathrm{H}_{2} \mathrm{O}$ (Con), 1 mM NaHS, $200 \mu \mathrm{M}$ hypotaurine $(\mathrm{HT})$, and $2 \mu \mathrm{M}$ DL-propargylglycine (PAG), alone or their combinations. After $12 \mathrm{~h}$, the confocal images of AzMC-dependent and DCF-dependent fluorescence in seedling roots were used to represent endogenous $\mathrm{H}_{2} \mathrm{~S}(\mathbf{a})$ and $\mathrm{H}_{2} \mathrm{O}_{2}$ (b) contents. Scale

$\mathrm{bar}=200 \mu \mathrm{m}$. Meanwhile, the relative fluorescence presented as values relative to Con $(\mathbf{c}, \mathbf{d})$. Also, the emerged LR density and the number of emerged LRs (>1 mm) per seedling (e) were analyzed with plants $4 \mathrm{~d}$ after treatments. Mean and SE values were calculated from at least three independent experiments. Within each set of experiments, bars denoted by the same letter did not differ significantly at $P<0.05$ according to Duncan's multiple range test

development. The results shown in Fig. 3 indicated that the addition of DMTU or DPI alone could bring about decreases in LR density (Fig. 3a and b), LR length (Fig. 3c), and LR number (Fig. 3d); while, the primary root (PR) length was increased (Fig. 3e). Further experiment revealed that both NaHS- and $\mathrm{H}_{2} \mathrm{O}_{2}$-induced lateral rooting were greatly reduced in the presence of DMTU and/or DPI. Microscopical analysis showed that NaHSand $\mathrm{H}_{2} \mathrm{O}_{2}$-induced LR primordia (LRP) presented a similar anatomic structure, and the inducing effects achieved by $\mathrm{NaHS}$ and $\mathrm{H}_{2} \mathrm{O}_{2}$ could be apparently prevented by DMTU or DPI (Fig. 4). Above results indicated a hypothesis that endogenous $\mathrm{H}_{2} \mathrm{O}_{2}$ might be required for $\mathrm{H}_{2} \mathrm{~S}$-induced lateral root development. Additionally, no additive responses were found when $\mathrm{NaHS}$ and $\mathrm{H}_{2} \mathrm{O}_{2}$ were applied together.

\section{$\mathrm{H}_{2} \mathrm{O}_{2}$ is required for lateral root formation triggered by $\mathrm{H}_{2} \mathrm{~S}$}

The role of $\mathrm{H}_{2} \mathrm{O}_{2}$ in $\mathrm{H}_{2} \mathrm{~S}$-induced lateral root development was further examined by monitoring $\mathrm{H}_{2} \mathrm{O}_{2}$ synthesis in response to applied NaHS. As expected, a significant increase in $\mathrm{H}_{2} \mathrm{O}_{2}$-related fluorescence was observed in NaHS-treated tomato seedling roots compared with control sample $(P<0.05)$, suggesting $\mathrm{H}_{2} \mathrm{~S}$-mediated $\mathrm{H}_{2} \mathrm{O}_{2}$ production (Fig. 2a and b). This deduction was confirmed by the co-treatment with DMTU and DPI. We also noticed that when NaHS was together with $\mathrm{H}_{2} \mathrm{O}_{2}$, there is no additive response in the fluorescence. The changes of endogenous $\mathrm{H}_{2} \mathrm{O}_{2}$ detected with spectrophotography showed the similar tendencies (Fig. 2C).

In order to assess the possible source(s) of $\mathrm{H}_{2} \mathrm{O}_{2}$, we thus evaluated the expression of $\mathrm{RBOH} 1$, the key gene responsible for $\mathrm{H}_{2} \mathrm{O}_{2}$ synthesis in tomato seedling roots [40]. As expected, a significant increase of $\mathrm{RBOH} 1$ expression was observed when tomato seedlings were incubated with NaHS, and the up-regulation of RBOH1 transcript was reversed by DMTU or DPI (Fig. 5). Meanwhile, a significant but weaker induction in $R B O H 1$ transcript was observed in response to the 


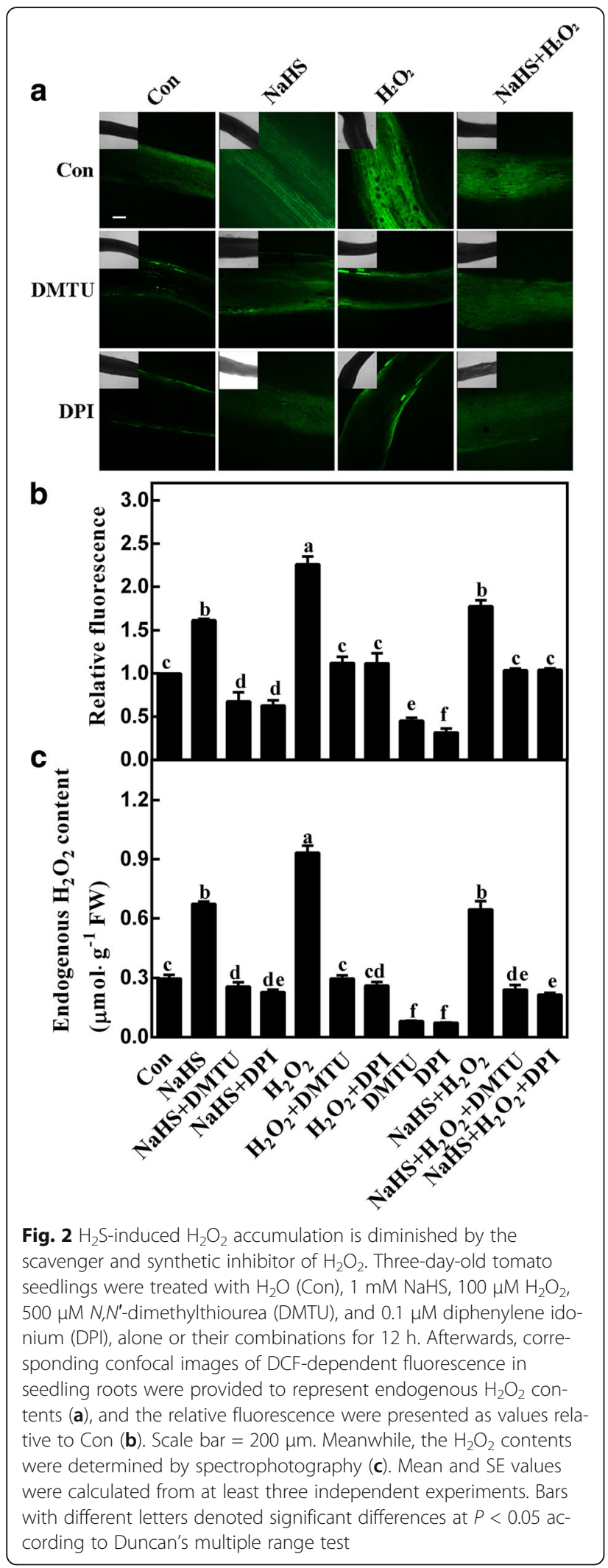

addition of $\mathrm{H}_{2} \mathrm{O}_{2}$ with or without NaHS. Above results indicated that $\mathrm{H}_{2} \mathrm{O}_{2}$ might be required for $\mathrm{LR}$ formation elicited by $\mathrm{H}_{2} \mathrm{~S}$.

$\mathrm{H}_{2} \mathrm{O}_{2}$ modulates the expression of cell cycle regulatory genes in $\mathrm{H}_{2} \mathrm{~S}$-induced $\mathrm{LR}$ formation

To further study the potential relationship between $\mathrm{H}_{2} \mathrm{O}_{2}$ and $\mathrm{H}_{2} \mathrm{~S}$ in the induction of LR formation, the influence of $\mathrm{NaHS}, \mathrm{H}_{2} \mathrm{O}_{2}$, DMTU, and DPI applied alone or their combination on the expression of cell cycle regulatory genes, was analyzed by qPCR. Similar to the inducible effects triggered by $\mathrm{H}_{2} \mathrm{O}_{2}$, NaHS resulted in the up-regulation of SlCYCA2;1, SlCYCA3;1, and SlCDKA1 transcripts, together with simultaneous downregulation of SlKRP2 transcripts (Fig. 6). However, DMTU or DPI significantly blocked above mentioned modulation in these transcripts triggered by treatments with $\mathrm{NaHS}$ and/or $\mathrm{H}_{2} \mathrm{O}_{2}$. These results indicated that $\mathrm{H}_{2} \mathrm{~S}$-triggered LR formation was likely to be achieved by up-regulation of $\mathrm{H}_{2} \mathrm{O}_{2}$-mediated cycle regulatory genes.

\section{Expression of miRNAs and their target genes}

In the subsequent experiments, several LR formationrelated miRNAs and their target genes were investigated to check whether they were involved in $\mathrm{H}_{2} \mathrm{~S}$-triggered LR development. Results shown in Fig. 7 revealed that both NaHS and $\mathrm{H}_{2} \mathrm{O}_{2}$ up-regulated miR390a and miR160 transcripts; while, their corresponding target genes, including SlARF4 and SlARF16, were significantly reduced. Contrasting changes were observed when $\mathrm{NaHS}$ or $\mathrm{H}_{2} \mathrm{O}_{2}$ was added together with DMTU or DPI. Above results confirmed the opposite effects between changes in miRNAs and their target genes.

\section{Detection of $\mathrm{S}$-sulfhydrated proteins in $\mathrm{H}_{2} \mathrm{~S}$-treated tomato}

To further analyze the molecular mechanism underlying $\mathrm{H}_{2} \mathrm{~S}$ signaling in LR formation, the pattern of $S$-sulfhydrated proteins in tomato roots was analyzed by using the modified biotin switch method. The results shown in Fig. 8a illustrated that treatment of tomato root extraction with $\mathrm{Na}_{2} \mathrm{~S}$ (another $\mathrm{H}_{2} \mathrm{~S}$ donor; [26]) enhanced $S$-sulfhydration, which was alleviated by DTT (a sulfhydration inhibitor; [24]). Consistently, tomato seedlings were treated with NaHS, HT, and PAG, alone or their combinations, then root extracts were used to analysis $S$-sulfhydrated profiles (Fig. 8B). Similarly, NaHS increased the level of $S$-sulfhydrated proteins, which was partially blocked by HT or PAG. Additionally, in compared with the control samples, HT or PAG alone slightly decreased sulfhydration. 


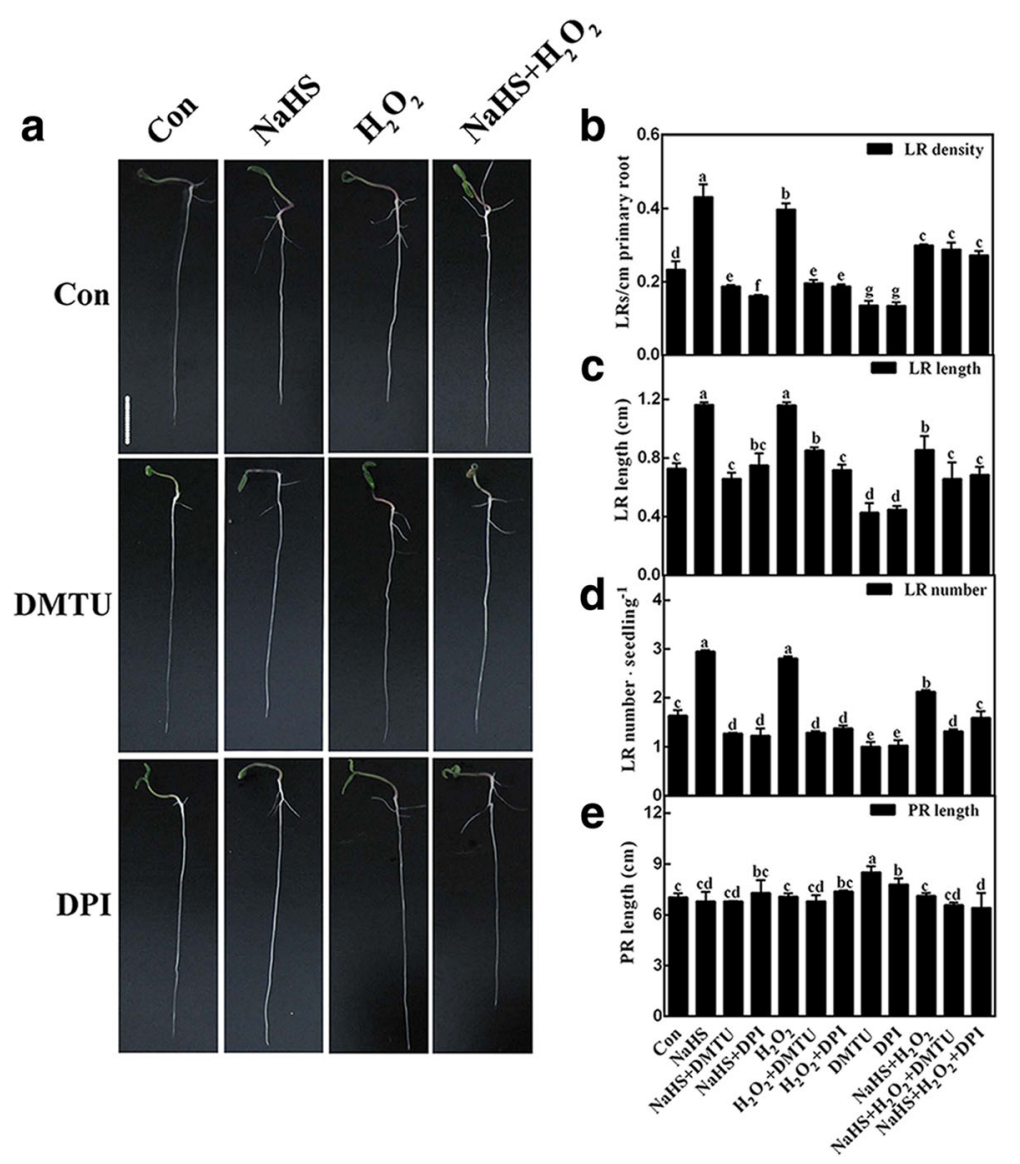

Fig. $3 \mathrm{H}_{2} \mathrm{~S}$-induced tomato lateral rooting is sensitive to the scavenger and synthetic inhibitor of $\mathrm{H}_{2} \mathrm{O}_{2}$. Three-day-old tomato seedlings were treated with $\mathrm{H}_{2} \mathrm{O}$ (Con), $1 \mathrm{mM} \mathrm{NaHS}, 100 \mu \mathrm{M} \mathrm{H}_{2} \mathrm{O}_{2}, 500 \mu \mathrm{M} \mathrm{N}, \mathrm{N}^{\prime}$-dimethylthiourea (DMTU), and $0.1 \mu \mathrm{M}$ diphenylene idonium (DPI), alone or their combinations for $4 \mathrm{~d}$. Corresponding photographs were taken $(\mathbf{a})$. Bar $=1 \mathrm{~cm}$. Meanwhile, the emerged LR density $(\mathbf{b})$, LR length $(\mathbf{c})$, the number of emerged LRs $(>1 \mathrm{~mm}$ ) per seedling $(\mathbf{d})$, and primary root (PR) length $(\mathbf{e})$ were analyzed. Mean and SE values were calculated from at least three independent experiments. Bars denoted by the same letter did not differ significantly at $P<0.05$ according to Duncan's multiple range test
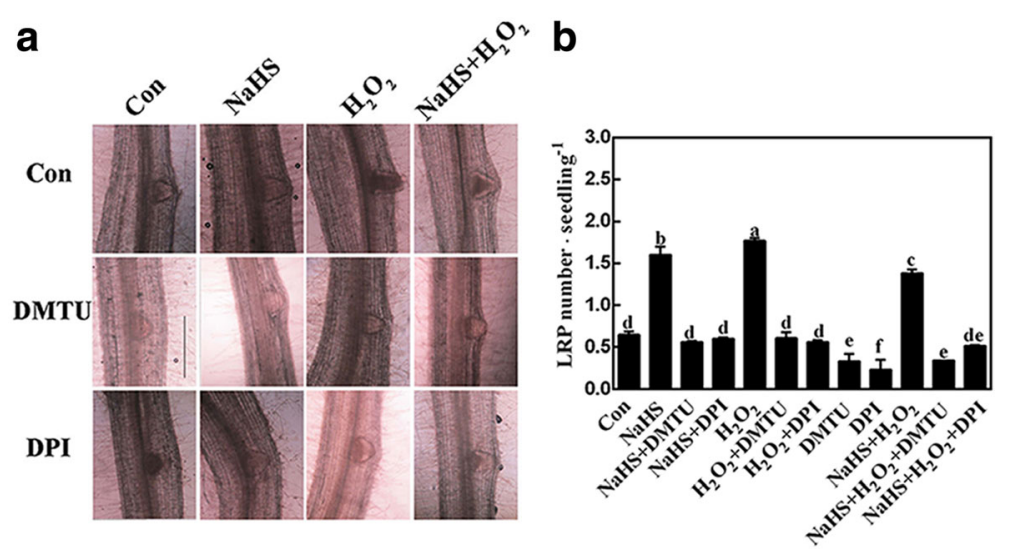

Fig. $4 \mathrm{H}_{2} \mathrm{~S}$-induced lateral root primordial (LRP) formation is sensitive to the removal of $\mathrm{H}_{2} \mathrm{O}_{2}$. Three-day-old tomato seedlings were treated with $\mathrm{H}_{2} \mathrm{O}$ (Con), $1 \mathrm{mM} \mathrm{NaHS}, 100 \mu \mathrm{M} \mathrm{H}_{2} \mathrm{O}_{2}, 500 \mu \mathrm{M} \mathrm{N}$, N'-dimethylthiourea (DMTU), and $0.1 \mu \mathrm{M}$ diphenylene idonium (DPI), alone or their combinations. After various treatments for $3 \mathrm{~d}$, photographs showing the representative morphology of LRP (about 75\% of LRP at the shown stages), were taken (a). Bar $=0.25 \mathrm{~mm}$. Meanwhile, the number of emerged LRP was also analyzed (b). Mean and SE values were calculated from at least three independent experiments. Bars with different letters denoted significant differences at $P<0.05$ according to Duncan's multiple range test 


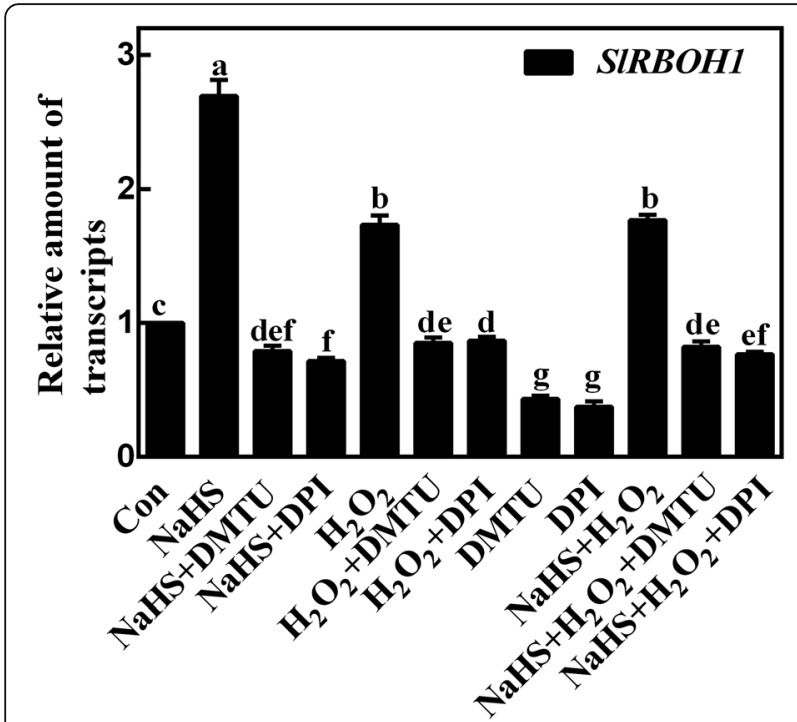

Fig. $5 \mathrm{H}_{2} \mathrm{~S}$ modulates the expression of SIRBOH1. Three-day-old tomato seedlings were treated with $\mathrm{H}_{2} \mathrm{O}$ (Con), $1 \mathrm{mM} \mathrm{NaHS}, 100 \mu \mathrm{M}$ $\mathrm{H}_{2} \mathrm{O}_{2}, 500 \mu \mathrm{M} N, N^{\prime}$-dimethylthiourea (DMTU), and $0.1 \mu \mathrm{M}$ diphenylene idonium (DPI), alone or their combinations, for $6 \mathrm{~h}$. Afterwards, the amount of transcript were analyzed by $\mathrm{qPCR}$, and presented relative to the Con. Mean and SE values were calculated from at least three independent experiments. Bars with different letters denoted significant differences at $P<0.05$ according to Duncan's multiple range test

\section{Discussion}

$\mathrm{H}_{2} \mathrm{~S}$ is proposed as the third gas messenger after $\mathrm{NO}$ and $\mathrm{CO}$ to fulfill many important roles in plants, including the inducement of $L R$ formation [23, 41, 42]. The important function of $\mathrm{H}_{2} \mathrm{O}_{2}$ in the auxin-induced $\mathrm{LR}$ formation was also illustrated [39]. Although $\mathrm{H}_{2} \mathrm{O}_{2}$ involved in $\mathrm{H}_{2} \mathrm{~S}$-induced salt tolerance pathway of the Arabidopsis root was discovered [43], the relationship between $\mathrm{H}_{2} \mathrm{~S}$ and $\mathrm{H}_{2} \mathrm{O}_{2}$ in LR formation is largely unclear. Here, we provided evidence for a previously unknown role for $\mathrm{H}_{2} \mathrm{O}_{2}$ in $\mathrm{H}_{2} \mathrm{~S}$-triggered LR formation in tomato seedlings.

Firstly, our results showed that an increase in the concentration of endogenous $\mathrm{H}_{2} \mathrm{O}_{2}$ determined by spectrophotography and LSCM, is one of the earliest responses involved in the signaling pathway governing LR formation triggered by $\mathrm{H}_{2} \mathrm{~S}$ (Figs. 1 and 2). These results are in agreement with those obtained in Arabidopsis subjected to salinity stress [43], showing that NaHS induced a gradual elevation of $\mathrm{H}_{2} \mathrm{O}_{2}$ in $\mathrm{NaCl}$-stressed seedling roots. This is an important point, since $\mathrm{H}_{2} \mathrm{O}_{2}$ is regarded as one of the ubiquitous components of the signaling transduction pathway [29], including responsible for the induction of LR formation [38, 39, 44] and adventitious rooting $[34,35]$.

Further pharmacological and microscopical evidence revealed the requirement of endogenous $\mathrm{H}_{2} \mathrm{O}_{2}$ in the
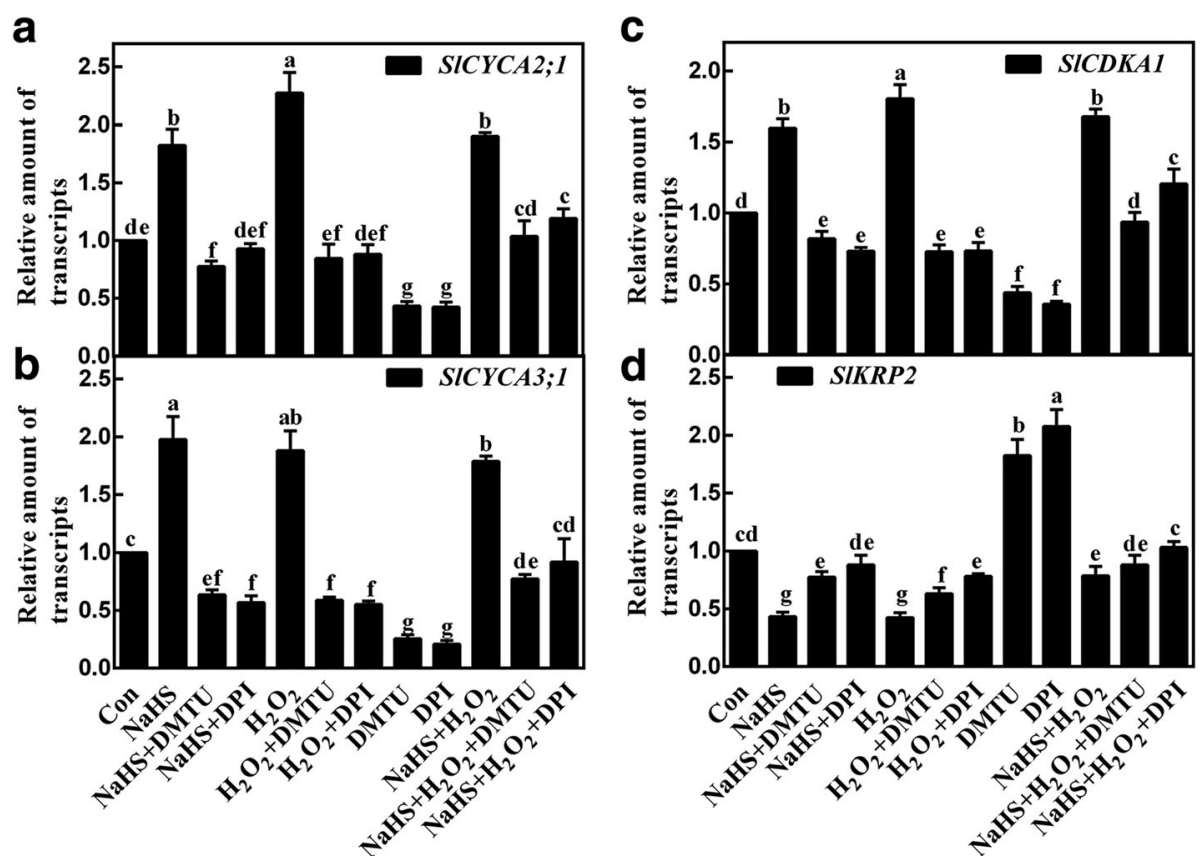

Fig. $6 \mathrm{H}_{2} \mathrm{~S}$ affects the expression of SICYCA2;1, SICYCA3;1, SICDKA1, and SIKRP2. Three-day-old tomato seedlings were treated with $\mathrm{H}_{2} \mathrm{O}$ (Con), $1 \mathrm{mM} \mathrm{NaHS}, 100 \mu \mathrm{M} \mathrm{H}_{2} \mathrm{O}_{2}, 500 \mu \mathrm{M} \mathrm{N}$, N'-dimethylthiourea (DMTU), and $0.1 \mu \mathrm{M}$ diphenylene idonium (DPI), alone or their combinations for $12 \mathrm{~h}$. Afterwards, SICYCA2;1 (a), SICYCA3;1 (b), SICDKA1 (c), and SIKRP2 (d) transcript levels were analyzed by qPCR, and presented relative to the Con. Mean and SE values were calculated from at least three independent experiments. Bars with different letters denoted significant differences at $P<0.05$ according to Duncan's multiple range test 


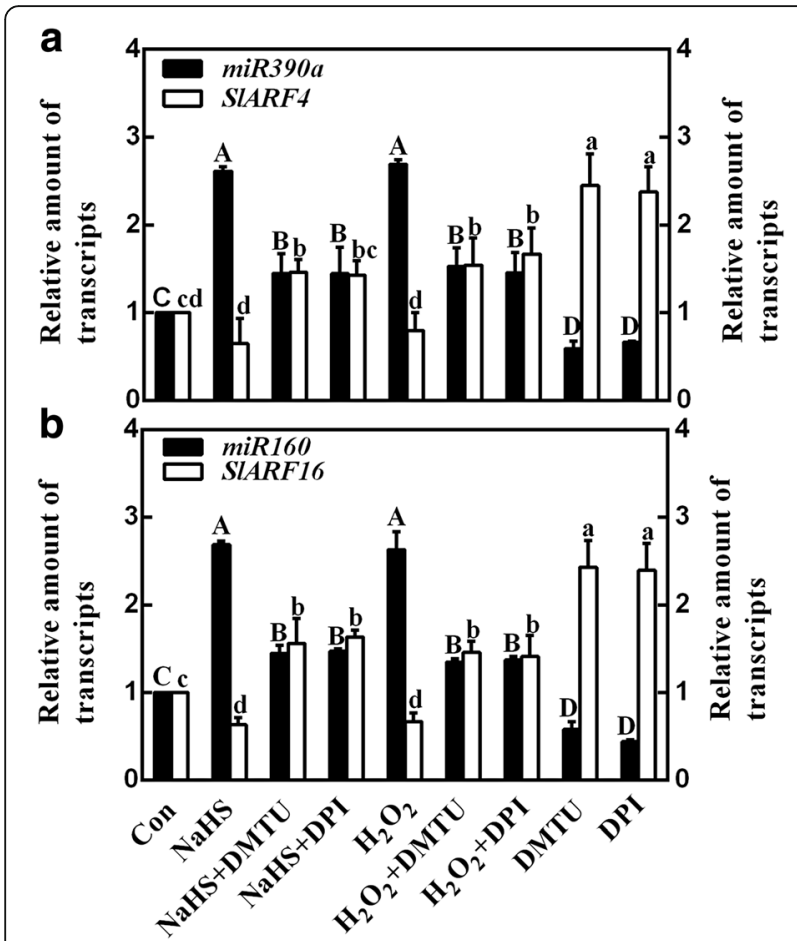

Fig. $7 \mathrm{H}_{2} \mathrm{~S}$ affects the expression of microRNAs and their target genes. Three-day-old tomato seedlings were treated with $\mathrm{H}_{2} \mathrm{O}$ (Con), $1 \mathrm{mM} \mathrm{NaHS}, 100 \mu \mathrm{M} \mathrm{H}_{2} \mathrm{O}_{2}, 500 \mu \mathrm{M} N$, N'-dimethylthiourea (DMTU), and $0.1 \mu \mathrm{M}$ diphenylene idonium (DPI), alone or their combinations for 12 h. Meanwhile, miR390a (a; black), SIARF4 (a; white), miR160 (b; black), and SIARF16 (b; white) transcript levels were analyzed by $\mathrm{qPCR}$, and presented relative to the Con. Mean and SE values were calculated from at least three independent experiments. Within each set of experiments, bars with different letters denoted significant differences at $P<0.05$ according to Duncan's multiple range test induction of tomato LR formation triggered by $\mathrm{H}_{2} \mathrm{~S}$. This conclusion is based on several pieces of evidence: (i) the removal of endogenous $\mathrm{H}_{2} \mathrm{O}_{2}$ by its membranepermeable scavenger DMTU impaired the induction of LR formation elicited by $\mathrm{H}_{2} \mathrm{~S}$ (Figs. 2 and 3); (ii) the similar inhibiting responses triggered by DPI, an inhibitor of NADPH oxidase, in $\mathrm{H}_{2} \mathrm{~S}$-induced $\mathrm{H}_{2} \mathrm{O}_{2}$ production (Fig. 2) and thereafter LRP formation and lateral rooting (Figs. 3 and 4) were significant, implying the involvement of tomato $\mathrm{RBOH} 1$, at least partially. Changes in SlRBOH1 transcripts confirmed this deduction (Fig. 5). Certainly, other candidate(s) for $\mathrm{H}_{2} \mathrm{O}_{2}$ synthesis (such as PAO and DAO; [36]) could not be easily ruled out in this process. Although we can not exclude the possibility that above mentioned chemicals may not specifically target $\mathrm{H}_{2} \mathrm{O}_{2}$, above results clearly indicated that $\mathrm{H}_{2} \mathrm{O}_{2}$ might be the downstream messenger of $\mathrm{H}_{2} \mathrm{~S}$ signaling responsible for LR formation. This deduction was consistent with the recent genetic results [45], showing that $R B O H$-mediated ROS production facilitated LR emergence in Arabidopsis.

Strong evidence proved that the expression of cell cycle regulatory genes plays important roles in the early LR initiation in the presence of auxin and $\mathrm{NO}[3,4,6]$. Similar to the previous results [23], our further molecular evidence revealed that $\mathrm{H}_{2} \mathrm{~S}$ could modulate four cell cycle regulatory genes, including SlCYCA2;1, SlCYCA3;1 SlCDKA1 and SlKRP2, mimicking the actions of $\mathrm{H}_{2} \mathrm{O}_{2}$ (Fig. 6). By contrast, the blocking effects were observed when DMTU or DPI was respectively supplemented together with $\mathrm{H}_{2} \mathrm{~S}$ and/or $\mathrm{H}_{2} \mathrm{O}_{2}$. Combined with the changes in phenotypes (Fig. 3), we further speculated that $\mathrm{H}_{2} \mathrm{~S}$-triggered $\mathrm{H}_{2} \mathrm{O}_{2}$ was important in the early LR initiation by targeting cell cycle regulatory genes.
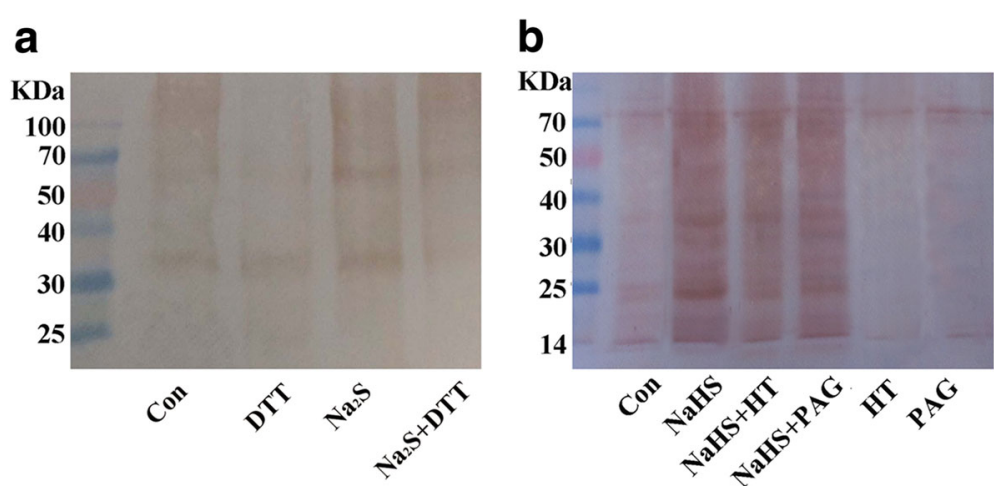

Fig. 8 Detection of S-sulfhydrated proteins. a Protein extracts from $0.25 \mathrm{~g}$ of tomato roots were exogenously treated with $\mathrm{H}_{2} \mathrm{O}(\mathrm{Con}), 2 \mathrm{mM} \mathrm{Na} \mathrm{S}_{2} \mathrm{~S}$ (for $1 \mathrm{~h}$; another $\mathrm{H}_{2} \mathrm{~S}$ donor), and $2 \mathrm{mM} \mathrm{DTT}$ (for $30 \mathrm{~min}$; a sulfhydration inhibitor), alone or their combinations (treatment with $\mathrm{Na}_{2} \mathrm{~S}$ followed by DTT), and subjected to the modified biotin switch method (BSM). Finally, the labeled proteins were detected using protein blot analysis with antibodies against biotin. b Three-day-old tomato seedlings were treated with $\mathrm{H}_{2} \mathrm{O}$ (Con), $1 \mathrm{mM} \mathrm{NaHS}, 200 \mu \mathrm{M}$ hypotaurine (HT), and 2 $\mu \mathrm{M}_{\mathrm{DL}}$-propargylglycine (PAG), alone or their combinations for $4 \mathrm{~d}$. Afterwards, protein extracts from $0.25 \mathrm{~g}$ of seedling roots were subjected to the BSM, and the labeled proteins were detected using protein blot analysis with antibodies against biotin. Representative pictures were provided 
It is well-known that plant miRNAs play an important role in leaf morphogenesis [46], leaf polarity [47, 48], flowering time $[49,50]$, and flower development [51]. Some studies also focused on miRNAs related to plant root organogenesis [52]. For example, Marin et al. [13] and Yoon et al. [53] revealed that miR390 and AUXIN RESPONSE FACTORS (ARFs) formed an auxinresponsive regulatory network (miR390-TAS3-ARF2/ $A R F 3 / A R F 4$ ) controlling lateral root development. Another miRNA, miR160, was confirmed to have a positive role in the induction of LR formation via targeting ARF16 in Arabidopsis [54]. Thus, several representative miRNAs correlated with ARFs and LR formation [52], including miR390a for SlARF4 [55], and miR160 for SlARF16 [54], were chosen. In this study, the results of qPCR revealed that miR390a and miR160 transcripts were increased by both $\mathrm{H}_{2} \mathrm{~S}$ and $\mathrm{H}_{2} \mathrm{O}_{2}$, and contrasting changes were observed in their target genes, including SlARF4 and SlARF16 (Fig. 7). Above mentioned changes were obviously prevented by the removal of endogenous $\mathrm{H}_{2} \mathrm{O}_{2}$ when DMTU or DPI was added together. These results were consistent with the changes in endogenous $\mathrm{H}_{2} \mathrm{O}_{2}$ levels (Fig. 2) and thereafter LR formation (Fig. 3). Thus, we deduced that auxin signaling mediated by $\mathrm{H}_{2} \mathrm{O}_{2}$-elicited miRNAs expression might be the important mechanism responsible for LR formation triggered by $\mathrm{H}_{2} \mathrm{~S}$. Certainly, corresponding genetic evidence should be investigated in the near future.

Recently, $\mathrm{H}_{2} \mathrm{~S}$-dependent $S$-sulfhydration, the conversion of cysteine $-\mathrm{SH}$ residues to persulfide $(-\mathrm{SSH})$ which could be detected by using a modified biotin switch method, has been described to play a vital role in mammalians and plants [26, 27]. Nevertheless, whether $S$ sulfhydration was involved in plant LR formation is still unknown. In our experimental conditions, the $S$-sulfhydration conditions were strengthened when protein extracts from tomato seedling roots were treated with $\mathrm{Na}_{2} \mathrm{~S}$ (another $\mathrm{H}_{2} \mathrm{~S}$ donor; [26]), and the addition of DTT (a sulfhydration inhibitor; [24]) impaired above effect (Fig. 8a). Since DTT could reduce disulfide bonds, our results suggested that the modification is covalent and involves a sulfhydryl group. Similar results were obtained when tomato seedlings were subjected to the chemicals related to the alternation of endogenous $\mathrm{H}_{2} \mathrm{~S}$ homeostasis (Fig. 8b). Thus, combine with the corresponding phenotypes in LR formation (Fig. 1), we provided a preliminary finding, that $S$-sulfhydration might be involved in $\mathrm{H}_{2} \mathrm{~S}$-promoted LR formation, although the specific $S$-sulfhydrated protein(s) had not been purified and elucidated. In fact, Aroca et al. [26] identified a total of $106 S$-sulfhydrated proteins in Arabidopsis, and some of the proteins (ascorbate peroxidase and catalase; etc) identified were related to reactive oxygen species (ROS) metabolism. Since it was shown that ROS acted downstream of auxin action in the development of LR emergence [45], and ascorbate peroxidase (APX; a scavenging enzyme of $\mathrm{H}_{2} \mathrm{O}_{2}$ ) was previously confirmed to be $S$-sulfhydrated [26], the genetic and biochemical (in vitro and in vivo tests) approaches combined with proteomic and transcriptomic analyses should be applied to check whether APX acts as the $S$-sulfhydrated target of $\mathrm{H}_{2} \mathrm{~S}$ signaling related to LR formation.

\section{Conclusions}

In summary, the results of this investigation indicated that an increase in $\mathrm{H}_{2} \mathrm{O}_{2}$ production might be an early response of $\mathrm{H}_{2} \mathrm{~S}$ that contributes to the induction of $\mathrm{LR}$ formation by (i) modulating the expression of cell cycle regulatory genes; (ii) regulating auxin signaling mediated by miRNAs expression; and (iii) at least partially involving $S$-sulfhydrated proteins (Fig. 9). Additionally, our results provide indications of transcriptional and posttranslational regulatory mechanism that contributed to the development of LR formation elicited by $\mathrm{H}_{2} \mathrm{~S}$.

\section{Methods}

\section{Chemicals}

All chemicals were purchased from Sigma (St Louis, MO, USA) unless stated otherwise. Sodium hydrosulfide (NaHS) was used at $1 \mathrm{mM}$ as a $\mathrm{H}_{2} \mathrm{~S}$ donor. $200 \mu \mathrm{M}$ hypotaurine ( $\mathrm{HT}$; an $\mathrm{H}_{2} \mathrm{~S}$ scavenger) and $2 \mu \mathrm{M}$ DL-propargylglycine (PAG; a synthetic inhibitor of $\mathrm{H}_{2} \mathrm{~S}$ ) were also used. Hydrogen peroxide $\left(\mathrm{H}_{2} \mathrm{O}_{2}\right)$ was applied at $100 \mu \mathrm{M}$. $N, N^{\prime}$-dimethylthiourea (DMTU), a scavenger of

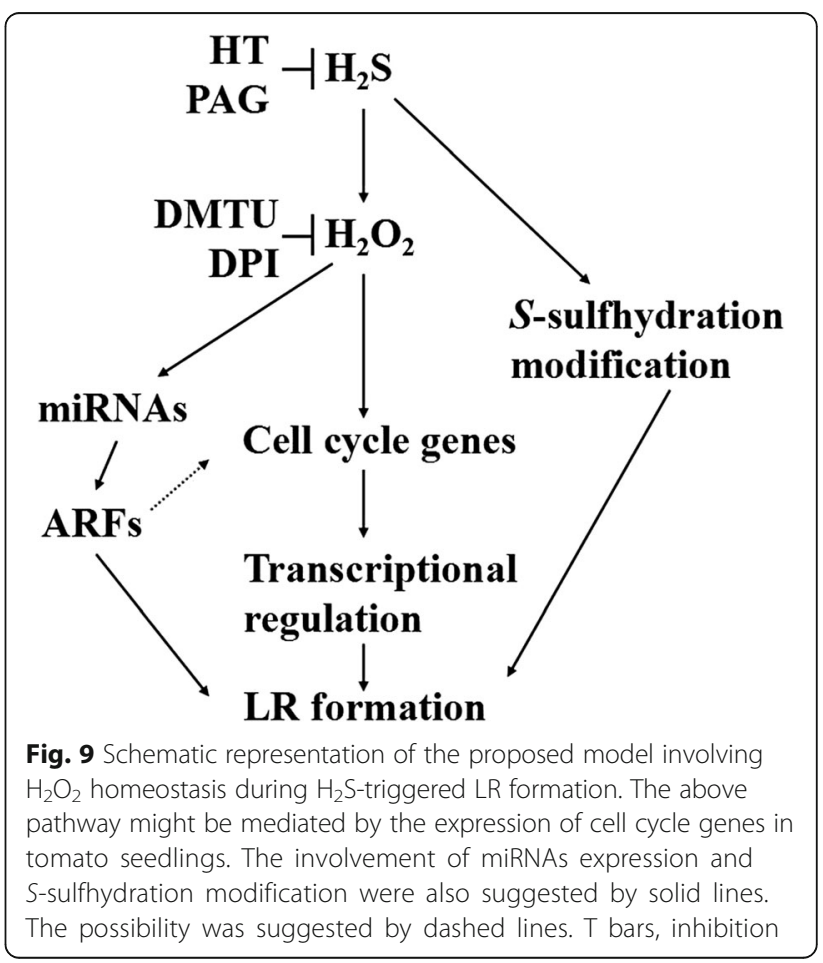


$\mathrm{H}_{2} \mathrm{O}_{2}$, was used at $500 \mu \mathrm{M}$. $0.1 \mu \mathrm{M}$ diphenylene idonium (DPI) was regarded as an inhibitor of $\mathrm{H}_{2} \mathrm{O}_{2}$ synthetic enzyme (NADPH oxidase). A $\mathrm{H}_{2} \mathrm{~S}$ fluorescent probe 7azido-4-methylcoumarin (AzMC) and a reactive oxygen species (ROS) fluorescent probe $2^{\prime}, 7^{\prime}$-dichlorofluorescein diacetate $\left(\mathrm{H}_{2} \mathrm{DCF}-\mathrm{DA}\right)$ were both used at a final concentration of $20 \mu \mathrm{M}$. According to our pilot experiments, the concentration of above chemicals exhibiting the effective responses was chosen.

\section{Plant material and growth conditions}

Tomato (Solanum lycopersicum L.) seeds "baiguoqiangfeng" were surface-sterilized in $2 \%$ sodium hypochlorite for $6 \mathrm{~min}$, rinsed extensively and germinated in distilled water at $25 \pm 1{ }^{\circ} \mathrm{C}$ in the dark for 3 days. Afterwards, the selected identical seedlings with radicles $2-3 \mathrm{~mm}$ were transferred to $4 \mathrm{ml}$ treatment solutions containing the indicated chemicals and grown in an illuminating incubator $\left(25 \pm 1{ }^{\circ} \mathrm{C}\right)$ with a light intensity of $200 \mu \mathrm{mol}$ $\mathrm{m}^{-2} \mathrm{~s}^{-1}$ at $14 / 10 \mathrm{~h}$ (light/dark) photoperiod.

After treatments for $4 \mathrm{~d}$ or the indicated time points, photographs were taken. Meanwhile, according to the previous methods [23, 39], the number of emerged lateral roots (LRs; $>1 \mathrm{~mm}$ ) per seedling, the length of primary root (PR), the length of $L R$ and the emerged LR density (the number of LR per $\mathrm{cm}$ primary root; LRs $/ \mathrm{cm}$ ) were determined by using Image $J$ software. Additionally, LR primordial (LRP) per seedling were observed after $3 \mathrm{~d}$ of treatments by root squash preparations and quantified with a light microscope. Unless stated otherwise, only the lateral root-inducible segments were used for the subsequent biochemical and molecular analyses. Thus, the root apical meristems were cut off, and the shoots of seedlings were removed by cutting below the root-shoot junction.

\section{Laser scanning confocal microscopy (LSCM)}

According to the previous methods with minor modification [56, 57], endogenous $\mathrm{H}_{2} \mathrm{O}_{2}$ and $\mathrm{H}_{2} \mathrm{~S}$ production were determined by a laser scanning confocal microscope (LSCM) using the ROS fluorescent probe $\mathrm{H}_{2}$ DCF-DA and a $\mathrm{H}_{2} \mathrm{~S}$ fluorescent probe AzMC. After treatments, roots were incubated in $20 \mathrm{mM}$ HEPES$\mathrm{NaOH}$ buffer $(\mathrm{pH} 7.5)$ containing $20 \mu \mathrm{M}$ probe for $30 \mathrm{~min}$ in dark $\left(25{ }^{\circ} \mathrm{C}\right)$. Afterwards, the roots were washed three times (15 min each time) with fresh HEPES buffer, and observed by using Zeiss LSM 710 confocal microscope (Carl Zeiss, Oberkochen, Germany) with the same exposure time.

All manipulations were performed at $25{ }^{\circ} \mathrm{C}$. Each photograph were taken at the eyepiece $5 \times$ magnification based on 20 overlapping confocal planes of $15 \mu \mathrm{m}$ each using ZEN software (300 $\mu \mathrm{m}$ sections along Z stack). For each picture, the overall fluorescence of maturation zone of the primary root (about an area of $500,000 \mu \mathrm{m}^{2}$ ), where cells become differentiated, and at a later stage lateral roots emerge, was quantified [9]. The bright-field (BF) images corresponding to the fluorescent images were also shown at the top left corners of the photograph. Representative photographs with similar results were obtained after the analysis of at least fifteen samples for each experiment. Afterwards, the average intensities of 15 photographs (1 photograph per sample) for each treatment were calculated. The relative fluorescence was presented as values relative to control sample.

\section{Measurement of $\mathrm{H}_{2} \mathrm{O}_{2}$ content}

The content of $\mathrm{H}_{2} \mathrm{O}_{2}$ was analyzed by the FOX1 method $[58,59]$. Samples were extracted with $200 \mathrm{mM}$ perchloric acid $\left(\mathrm{HClO}_{4}\right)$. After centrifugation at $4{ }^{\circ} \mathrm{C}, 10,000 \mathrm{~g}$ for $15 \mathrm{~min}, 500 \mu \mathrm{L}$ supernatant was transferred to $500 \mu \mathrm{L}$ assay solution containing $500 \mu \mathrm{M}$ ammonium ferrous sulfate, $50 \mathrm{mM} \mathrm{H}_{2} \mathrm{SO}_{4}, 200 \mu \mathrm{M}$ xylenol orange, and $200 \mathrm{mM}$ sorbitol, for $45 \mathrm{~min}$ in dark $\left(25^{\circ} \mathrm{C}\right)$. Afterwards, the absorbance values were detected at $560 \mathrm{~nm}$. The specificity for $\mathrm{H}_{2} \mathrm{O}_{2}$ was tested by eliminating $\mathrm{H}_{2} \mathrm{O}_{2}$ in the reaction mixture with catalase (CAT). Standard curves of $\mathrm{H}_{2} \mathrm{O}_{2}$ were obtained for each independent experiment by adding variable amounts of $\mathrm{H}_{2} \mathrm{O}_{2}$.

\section{Quantitative real-time RT-PCR (qPCR) analysis}

qPCR was used to analyze the expression of cell cycle regulatory genes, ARFs genes, and miRNA. After various treatments, total RNA from about $100 \mathrm{mg}$ (fresh weight) samples was isolated by using Trizol reagent (Invitrogen, Gaithersburg, MD, USA). Afterwards, the RNA samples were reverse-transcribed using an oligo $\mathrm{d}(\mathrm{T})$ primer and M-MLV reverse transcriptase (BioTeke, Beijing, China). Quantitative RT-PCR reactions were performed using a Mastercycler ep realplex real-time PCR system (Eppendorf, Hamburg, Germany) with SYBR $^{\odot}$ Premix Ex Taq ${ }^{\text {Ta }}$ (TransGen Biotech, Beijing, China) according to the manufacturer's instructions. The accession numbers (GenBank/miRBase) and oligonucleotide primers were shown in Additional file 1: Table S1. Three biological and three technological repeats were performed in qPCR. Relative expression levels of corresponding genes were calculated by using the $2_{\mathrm{T}}^{-\Delta \Delta C}$ method [60, 61], and were presented as values relative to that of corresponding control samples at the indicated times, after normalization with Actin and GAPDH transcript levels.

A One Step PrimeScript miRNA cDNA synthesis kit (TaKaRa Bio Inc., Dalian, China) was used to synthesize cDNA for analyzing miRNA expression by qPCR. The specific 5' primers were listed in Additional file 1: Table S1. The 3' primer was supplied in the kit. U6 snRNA was used as internal control. The rest steps were the same as the approaches described previously [62]. 


\section{Modified biotin switch method}

The modified biotin switch method was carried out as previously described protocol with minor modification $[26,63]$. Total proteins extracted from samples were homogenized in HEN buffer containing $250 \mathrm{mM}$ Hepes$\mathrm{NaOH}$ (pH 7.7), $1 \mathrm{mM}$ EDTA and $0.1 \mathrm{mM}$ neocuproine, and centrifuged at $10000 \mathrm{~g}$ for $15 \mathrm{~min}$ at $4{ }^{\circ} \mathrm{C}$. The supernatant was transferred to fresh tubes, and added with three volumes of blocking buffer (HEN buffer supplemented with $2.5 \%$ SDS and $20 \mathrm{mM}$ methyl methanethiosulfonate (MMTS)). Then, the solution was incubated at $4{ }^{\circ} \mathrm{C}$ for $12 \mathrm{~h}$ to block free sulfhydryl groups. The MMTS was then removed, and ice-cold acetone was used to precipitate the proteins at $-20{ }^{\circ} \mathrm{C}$ for $20 \mathrm{~min}$. After the removal of acetone, the proteins were resuspended in HENS buffer (HEN buffer supplemented with $1 \% \mathrm{SDS})$. Afterwards, the $S$-sulfhydrated proteins were labeled using $4 \mathrm{mM} \mathrm{N}$-[6-(biotinamido)hexyl]-3'(2'-pyridyldithio)propionamide (Biotin-HPDP) for $3 \mathrm{~h}$ at $25^{\circ} \mathrm{C}$ in the dark.

The above biotin-labeled proteins were separated using non-reducing SDS-PAGE on $12 \%$ polyacrylamide gels. Then, the proteins were transferred to polyvinylidene fluoride membranes (Roche, Basel, Switzerland) according to the manufacturer's instructions. Anti-biotin antibody (HRP) (Abcam antibodies, Cambridge, UK) was diluted 1:10,000. Meanwhile, Coomassie Brilliant Blue-stained gels were used to confirm the equal amounts of proteins loaded (data not shown).

\section{Statistical analysis}

All results were shown as the mean values \pm SE of at least three independent experiments with at least three biological replicates for each. By using SPSS 17.0 software, data was analyzed by one-way analysis of variance (ANOVA) followed by Duncan's multiple range test, and $P$ values $<0.05$ were considered statistically significant.

\section{Additional file}

Additional file 1: Table S1. The accession numbers and primer sequences of real-time RT-PCR (qPCR). (DOC $45 \mathrm{~kb}$ )

\section{Abbreviations}

3-MST: 3-Mercaptopyruvate sulfurtransferase; APX: Ascorbate peroxidase; ARFs: Auxin response factors; AzMC: 7-Azido-4-methylcoumarin; Biotin-HPDP: N-[6-(Biotinamido)hexyl]-3'-(2'-pyridyldithio)propionamide; CAT: Catalase; CBS: Cystathionine- $\beta$-synthase; CDK: Cyclin Dependent Kinases; CO: Carbon monoxide; CSE: Cystathionine- $\gamma$-lyase; DAO: Diamine oxidases; DMTU: Dimethylthiourea; DPI: Diphenylene idonium; $\mathrm{H}_{2}$ DCF-DA: 2',7'Dchlorofluorescein diacetate; $\mathrm{H}_{2} \mathrm{O}_{2}$ : Hydrogen peroxide; $\mathrm{H}_{2} \mathrm{~S}$ : Hydrogen sulfideHRPAnti-biotin antibody; HT: Hypotaurine; LR: Lateral root; LRP: Lateral root primordial; LSCM: Laser scanning confocal microscopy; MiRNAs: MicroRNAs; MMTS: Methyl methanethiosulfonate; NaHS: Sodium hydrosulfide; NO: Nitric oxide; PAG: DL-Propargylglycine; PAO: Polyamine oxidases; PR: Primary root; ROS: Reactive oxygen species; qPCR: Quantitative real-time RT-PCR

\section{Acknowledgements}

None.

\section{Funding}

This work was supported by the National Natural Science Foundation of China (31772292), the Natural Science Foundation of Jiangsu Province of China (BK20141361), and the Priority Academic Program Development of Jiangsu Higher Education Institutions (PAPD).

Availability of data and materials

All relevant data are within this article and its supporting information files.

\section{Authors' contributions}

Conception and design of the study: LH. Acquisition of data for the study: YM, HC, WS', and WS ${ }^{2}$. Analysis of data for the work: YM and $\mathrm{WS}^{1}$. Interpretation of data for the work: YM, HC, WS ${ }^{1}, W^{2}$, and LH. All authors read and approved the final manuscript.

\section{Ethics approval and consent to participate}

Tomato (Solanum lycopersicum L.) seeds "baiguoqiangfeng" were purchased from Jiangsu Academy of Agricultural Sciences. The Tomato seeds have obtained the permission of Ministry of Agriculture of the People's Republic of China, which the phytosanitary certificate number is $620,900,200,000,857$

\section{Consent for publication}

Not applicable.

\section{Competing interests}

The authors declare that they have no competing interests.

\section{Publisher's Note}

Springer Nature remains neutral with regard to jurisdictional claims in published maps and institutional affiliations.

\section{Author details}

${ }^{1}$ College of Life Sciences, Laboratory Center of Life Sciences, Nanjing Agricultural University, Nanjing 210095, China. ${ }^{2}$ College of Sciences, Nanjing Agricultural University, Nanjing 210095, China.

Received: 7 May 2017 Accepted: 9 October 2017

Published online: 13 October 2017

\section{References}

1. Casimiro I, Marchant A, Bhalerao RP, Beeckman T, Dhooge S, Swarup R, et al. Auxin transport promotes Arabidopsis lateral root initiation. Plant Cell. 2001;13:843-52.

2. Malamy JE. Intrinsic and environmental response pathways that regulate root system architecture. Plant Cell Environ. 2005;28:67-77.

3. Himanen K, Boucheron E, Vanneste S, de Almeida EJ, Inzé D, Beeckman T. Auxin-mediated cell cycle activation during early lateral root initiation. Plant Cell. 2002;14:2339-51.

4. Himanen K, Vuylsteke M, Vanneste S, Vercruysse S, Boucheron E, Alard P, et al. Transcript profiling of early lateral root initiation. Proc Natl Acad Sci U S A. 2004;101:5146-51

5. Casimiro I, Beeckman T, Graham N, Bhalerao R, Zhang $H$, Casero $P$, et al. Dissecting Arabidopsis lateral root development. Trends Plant Sci. 2003;8:165-71.

6. Correa-Aragunde N, Graziano M, Chevalier C, Lamattina L. Nitric oxide modulates the expression of cell cycle regulatory genes during lateral root formation in tomato. J Exp Bot. 2006;57:581-8.

7. Guilfoyle TJ, UImasov T, Hagen G. The ARF family of transcription factors and their role in plant hormone-responsive transcription. Cel Mol Life Sci. 1998;54:619-27.

8. Lee HW, Kim NY, Lee DJ, Kim J. LBD18/ASL20 regulates lateral root formation in combination with LBD16/ASL18 downstream of ARF7 and ARF19 in Arabidopsis. Plant Physiol. 2009;151:1377-89.

9. Zhu D, Mei Y, Shi Y, Hu D, Ren Y, Gu Q, et al. Involvement of glutathione in $\beta$-cyclodextrin-hemin complex-induced lateral root formation in tomato seedlings. J Plant Physiol. 2016;204:92-100. 
10. He L, Hannon GJ. MicroRNAs: small RNAs with a big role in gene regulation. Nat Rev Genet. 2004;5:522-31.

11. Megraw M, Baev V, Rusinov V, Jensen ST, Kalantidis K, Hatzigeorgiou AG. MicroRNA promoter element discovery in Arabidopsis. RNA. 2006;12:1612-9

12. Zhang B, Pan X, Wang Q, Cobb GP, Anderson TA. Computational identification of microRNAs and their targets. Comput Biol Chem. 2006;30:395-407.

13. Marin E, Jouannet V, Herz A, Lokerse AS, Weijers D, Vaucheret $H$, et al. miR390, Arabidopsis TAS3 tasiRNAs, and their AUXIN RESPONSE FACTOR targets define an autoregulatory network quantitatively regulating lateral root growth. Plant Cell. 2010;22:1104-17.

14. Mallory AC, Bartel DP, Bartel B. MicroRNA-directed regulation of Arabidopsis AUXIN RESPONSE FACTOR17 is essential for proper development and modulates expression of early auxin response genes. Plant Cell. 2005;17:1360-75.

15. Wang R. Two's company, three's a crowd: can $\mathrm{H}_{2} \mathrm{~S}$ be the third endogenous gaseous transmitter? FASEB J. 2002;16:1792-8.

16. García-Mata C, Lamattina L. Hydrogen sulphide, a novel gasotransmitter involved in guard cell signalling. New Phytol. 2010;188:977-84.

17. Zhang H, Tang J, Liu XP, Wang Y, Yu W, Peng WY, et al. Hydrogen sulfide promotes root organogenesis in Ipomoea batatas, Salix matsudana, and Glycine max. J Integr Plant Biol. 2009;51:1086-94.

18. Zhang H, Hu LY, Hu KD, He YD, Wang SH, Luo JP. Hydrogen sulfide promotes wheat seed germination and alleviates oxidative damage against copper stress. J Integr Plant Biol. 2008:50:1518-29.

19. Olas B. Hydrogen sulfide in signaling pathways. Clin Chim Acta. 2015;439:212-8.

20. Guo H, Xiao T, Zhou H, Xie Y, Shen W. Hydrogen sulfide: a versatile regulator of environmental stress in plants. Acta Physiol Plant. 2016:38:1-13.

21. Papenbrock J, Riemenschneider A, Kamp A, Schulz-Vogt HN, Schmidt A. Characterization of cysteine-degrading and $\mathrm{H}_{2} \mathrm{~S}$-releasing enzymes of higher plants-from the field to the test tube and back. Plant Biol (Stuttg). 2007;9:582-8

22. Álvarez C, Calo L, Romero LC, García I, Gotor C. An O-acetylserine(thiol)lyase homolog with L-cysteine desulfhydrase activity regulates cysteine homeostasis in Arabidopsis. Plant Physiol. 2010;152:656-69.

23. Fang T, Cao Z, Li J, Shen W, Huang L. Auxin-induced hydrogen sulfide generation is involved in lateral root formation in tomato. Plant Physiol Biochem. 2014;76:44-51.

24. Mustafa AK, Gadalla MM, Sen N, Kim S, Mu W, Gazi SK, et al. $\mathrm{H}_{2} \mathrm{~S}$ signals through protein S-sulfhydration. Sci Signal. 2009;2:ra72.

25. Paul BD, Snyder $\mathrm{SH} . \mathrm{H}_{2} \mathrm{~S}$ signalling through protein sulfhydration and beyond. Nat Rev Mol Cell Biol. 2012;13:499-507.

26. Aroca Á, Serna A, Gotor C, Romero LC. S-sulfhydration: a cysteine posttranslational modification in plant systems. Plant Physiol. 2015;168:334-42.

27. Lu C, Kavalier A, Lukyanov E, Gross SS. S-sulfhydration/desulfhydration and S-nitrosylation/denitrosylation: a common paradigm for gasotransmitter signaling by $\mathrm{H}_{2} \mathrm{~S}$ and NO. Methods. 2013;62:177-81.

28. Bouchereau A, Aziz A, Larher F, Martin-Tanguy J. Polyamines and environmental challenges: recent developments. Plant Sci. 1999;140:103-25.

29. Neill S, Desikan R, Hancock J. Hydrogen peroxide signaling. Curr Opin Plant Biol. 2002;5:388-95.

30. Pei ZM, Murata Y, Benning G, Thomine S, Klüsener B, Allen GJ, et al. Calcium channels activated by hydrogen peroxide mediate abscisic acid signalling in guard cells. Nature. 2000:406:731-4.

31. Joo JH, Bae YS, Lee JS. Role of auxin-induced reactive oxygen species in root gravitropism. Plant Physiol. 2001;126:1055-60.

32. Foreman J, Demidchik V, Bothwell JH, Mylona P, Miedema H, Torres MA, et al. Reactive oxygen species produced by NADPH oxidase regulate plant cell growth. Nature. 2003;422:442-6.

33. Song YJ, Joo JH, Ryu HY, Lee JS, Bae YS, Nam KH. Reactive oxygen species mediate IAA-induced ethylene production in mungbean (Vigna radiata $\mathrm{L}$.) hypocotyls. J Plant Biol. 2007;50:18-23.

34. Bai X, Todd CD, Desikan R, Yang Y, Hu X. N-3-oxo-decanoyl-_-homoserinelactone activates auxin-induced adventitious root formation via hydrogen peroxide- and nitric oxide-dependent cyclic GMP signaling in mung bean. Plant Physiol. 2012;158:725-36.

35. Li S, Xue L, Xu S, Feng H, An L. Hydrogen peroxide involvement in formation and development of adventitious roots in cucumber. Plant Growth Regul. 2007:52:173-80.
36. Su GX, Zhang WH, Liu YL. Involvement of hydrogen peroxide generated by polyamine oxidative degradation in the development of lateral roots in soybean. J Integr Plant Biol. 2006:48:426-32.

37. Wang $P$, Du Y, Li Y, Ren D, Song CP. Hydrogen peroxide-mediated activation of MAP kinase 6 modulates nitric oxide biosynthesis and signal transduction in Arabidopsis. Plant Cell. 2010;22:2981-98.

38. Chen $\mathrm{YH}$, Chao YY, Hsu YY, Kao CH. Heme oxygenase is involved in $\mathrm{H}_{2} \mathrm{O}_{2}$-induced lateral root formation in apocynin-treated rice. Plant Cell Rep. 2013;32:219-26.

39. Ma F, Wang L, Li J, Samma MK, Xie Y, Wang R, et al. Interaction between $\mathrm{HY} 1$ and $\mathrm{H}_{2} \mathrm{O}_{2}$ in auxin-induced lateral root formation in Arabidopsis. Plant Mol Biol. 2013;85:49-61.

40. Yi C, Yao K, Cai S, Li H, Zhou J, Xia X, et al. High atmospheric carbon dioxide-dependent alleviation of salt stress is linked to RESPIRATORY BURST OXIDASE 1 ( $\mathrm{RBOH}$ 1)-dependent $\mathrm{H}_{2} \mathrm{O}_{2}$ production in tomato (Solanum lycopersicum). J Exp Bot. 2015;66:7391-404.

41. Correa-Aragunde N, Graziano M, Lamattina L. Nitric oxide plays a central role in determining lateral root development in tomato. Planta. 2004;218:900-5.

42. Cao ZY, Xuan W, Liu ZY, Li XN, Zhao N, Xu P, et al. Carbon monoxide promotes lateral root formation in rapeseed. J Integr Plant Biol. 2007:49:1070-9.

43. Li J, Jia H, Wang J, Cao Q, Wen Z. Hydrogen sulfide is involved in maintaining ion homeostasis via regulating plasma membrane $\mathrm{Na}^{+} / \mathrm{H}^{+}$ antiporter system in the hydrogen peroxide-dependent manner in saltstress Arabidopsis Thaliana root. Protoplasma. 2014;251:899-912.

44. Cao Z, Fang T, Chen M, Li J, Shen W, Huang L. Involvement of haem oxygenase-1 in hydrogen peroxide-induced lateral root formation in tomato. Acta Physiol Plant. 2014;36:931-43.

45. Orman-Ligeza B, Parizot B, de Rycke R, Fernandez A, Himschoot E, Van Breusegem $F$, et al. RBOH-mediated ROS production facilitates lateral root emergence in Arabidopsis. Development. 2016;143:3328-39.

46. Palatnik JF, Allen E, Wu X, Schommer C, Schwab R, Carrington JC, et al. Control of leaf morphogenesis by microRNAs. Nature. 2003;425:257-63.

47. Juarez MT, Kui JS, Thomas J, Heller BA, Timmermans MC. MicroRNA-mediated repression of rolled leaf1 specifies maize leaf polarity. Nature. 2004;428:84-8.

48. Kidner CA, Martienssen RA. Spatially restricted microRNA directs leaf polarity through ARGONAUTE1. Nature. 2004;428:81-4.

49. Chen X. A microRNA as a translational repressor of APETALA2 in Arabidopsis flower development. Science. 2004;303:2022-5.

50. Lee H, Yoo SJ, Lee JH, Kim W, Yoo SK, Fitzgerald H, et al. Genetic framework for flowering-time regulation by ambient temperature-responsive miRNAs in Arabidopsis. Nucleic Acids Res. 2010;38:3081-93.

51. Laufs $P$, Peaucelle A, Morin $H$, Traas J. MicroRNA regulation of the CUC genes is required for boundary size control in Arabidopsis meristems. Development. 2004;131:4311-22

52. Yin Z, Li C, Han X, Shen F. Identification of conserved microRNAs and their target genes in tomato (Lycopersicon esculentum). Gene. 2008;414:60-6.

53. Yoon EK, Yang JH, Lim J, Kim SH, Kim SK, Lee WS. Auxin regulation of the microRNA390-dependent transacting small interfering RNA pathway in Arabidopsis lateral root development. Nucleic Acids Res. 2010;38:1382-91.

54. Wang JW, Wang LJ, Mao YB, Cai WJ, Xue HW, Chen XY. Control of root cap formation by microRNA-targeted auxin response factors in Arabidopsis. Plant Cell. 2005;17:2204-16.

55. Meng $Y$, Ma X, Chen D, Wu P, Chen M. MicroRNA-mediated signaling involved in plant root development. Biochem Bioph Res Co. 2010;393:345-9.

56. Xie Y, Mao Y, Zhang W, Lai D, Wang Q, Shen W. Reactive oxygen speciesdependent nitric oxide production contributes to hydrogen-promoted stomatal closure in Arabidopsis. Plant Physiol. 2014;165:759-73.

57. Liu D, Xu S, Hu H, Pan J, Li P, Shen W. Endogenous hydrogen sulfide homeostasis is responsible for the alleviation of senescence of postharvest daylily flower via increasing antioxidant capacity and maintained energy status. J Agr Food Chem. 2017;65:718-26.

58. Jiang ZY, Woollard ACS, Wolff SP. Hydrogen peroxide production during experimental protein glycation. FEBS Lett. 1990;268:69-71.

59. Bellincampi D, Dipierro N, Salvi G, Cervone F, De Lorenzo G. Extracellular $\mathrm{H}_{2} \mathrm{O}_{2}$ induced by oligogalacturonides is not involved in the inhibition of the auxin-regulated rolB gene expression in tobacco leaf explants. Plant Physiol. 2000;122:1379-85. 
60. Livak KJ, Schmittgen TD. Analysis of relative gene expression data using real-time quantitative PCR and the $2 T^{-\Delta \Delta C}$ method. Methods. 2001;25:402-8.

61. Schmittgen TD, Livak KJ. Analyzing real-time PCR data by the comparative $C_{T}$ method. Nat Protoc. 2008:3:1101-8.

62. Xu S, Jiang Y, Cui W, Jin Q, Zhang Y, Bu D, et al. Hydrogen enhances adaptation of rice seedlings to cold stress via the reestablishment of redox homeostasis mediated by miRNA expression. Plant Soil. 2017:414:53-67.

63. Qi F, Xiang Z, Kou N, et al. Nitric oxide is involved in methane-induced adventitious root formation in cucumber. Physiol Plant. 2017;159:366-77.

Submit your next manuscript to BioMed Central and we will help you at every step:

- We accept pre-submission inquiries

- Our selector tool helps you to find the most relevant journal

- We provide round the clock customer support

- Convenient online submission

- Thorough peer review

- Inclusion in PubMed and all major indexing services

- Maximum visibility for your research

Submit your manuscript at www.biomedcentral.com/submit
Biomed Central 